\title{
Geosciencences
}

http://dx.doi.org/10.1590/0370-44672016710123

Ricardo Eustáquio Fonseca Filho ${ }^{1}$ Angélica Fortes Drummond Chicarino Varajão ${ }^{2}$ Múcio do Amaral Figueiredo ${ }^{3}$ Paulo de Tarso Amorim Castro ${ }^{4}$

'Professor-Adjunto, Universidade Federal de Ouro Preto - UFOP, Departamento de Turismo, Ouro

Preto - Minas Gerais - Brasil.

ricardo.fonseca@ufop.edu.br

${ }^{2}$ Professora-Titular, Universidade Federal de Ouro Preto - UFOP, Escola de Minas, Departamento de Engenharia Geológica, Ouro Preto - Minas Gerais - Brasil. angelicavarajao@gmail.com

${ }^{3}$ Professor-Associado, Universidade Federal de São Joao del-Rei - UFSJ, Departamento de Geociências, São Joao del-Rei - Minas Gerais - Brasil. muciofigueiredo@ufsj.edu.br

${ }^{4}$ Professor-Titular, Universidade Federal de Ouro Preto UFOP, Escola de Minas, Departamento de Engenharia Geológica, Ouro Preto - Minas Gerais - Brasil. paulo_de_tarso@degeo.ufop.br

\section{Pedological aspects as environmental quality indicators of a touristic trail in the Serra do Cipó National Park/MG}

\author{
Abstract
}

Soil provides important support for anthropogenic activities, and earthen trails, which have always been present in the natural landscape, are routes of access to various tourist attractions. In recent decades, trails have been widely used as a method of access and visitation to geotouristic attractions. Because trails are restricted routes, transit along these paths also transforms the route into a pathway for the spread of various negative environmental impacts, including compaction and soil erosion of the trailbed. Soil compaction is caused by changes in the soil structure that are partly induced by the use of agricultural or geotechnical machinery and traffic, and the damage is also manifested in a remarkable decrease in porosity, which has clear implications for the infiltration and percolation of water and air associated with the functional porosity of soil. Soil micromorphological characteristics contribute to the analysis of soil porous systems, and the macroporous characteristics visible at this scale include the size, shape and connectivity among voids, which can be studied using different methods of identification, measurement and interpretation. Such methods are applied to understand the pore genesis and, more importantly, the physical behavior of soil-water order management. This work presents the results of analyses of the macromorphological and micromorphological characteristics, porosity, texture and penetrometry resistance of soil profiles on the Farofa Waterfall trail in the Serra do Cipó National Park, and the aim is to provide recommendations for compaction studies along special trails. The results showed that most of the trailbed is more compressed than at the margins, which suggests the need for geoindicator studies of soil quality to monitor the visitation of the trail and improve the conservation of natural resources.

Keywords: soil compaction; soil quality; soil micromorphology; geotourism; trail.

\section{Introduction}

Although trails are pathways for transit, they also represent one of the attractions of protected natural areas, and park trails are managed according to planning needs, implementation and monitoring policies. Trail assessment studies have considered different variables; however, most have not considered the micromorphological aspects of soil porosity. Soil micromorphology was initially defined in 1938 by Kubiëna. In 1964, Brewer published another article based on the structure and mineralogy of soil. Microscopic observations gained increasing attention in the mid-1970s to 1980s with the work of Fitzpatrick (1984) and Bullock et al. (1985a).

The study of soil porosity has many applications in agriculture and geotechnoloy and for investigating the impacts of recreation. The techniques and instruments associated with micromorphology, such as optical microscopy, can greatly assist in the identification of environmental impacts, such as soil compaction; may contribute to better soil management; and can provide insights to help educate visitors about soil quality and conservation. The concept of soil quality emerged in the 1990s and has been a subject of discussion because of its lack of consensus among scholars (Karlen et al., 1997, 2003). The term "capacity of the soil to work" reflects that soil is a dynamic living system. Moreover, evaluations of soil quality are relative because of the varied nature and specific functions of soil; thus, the quality of soil can differ without being limiting.

Karlen et al. (1997) defined the following soil quality indicators: organic matter, infiltration, aggregation, $\mathrm{pH}$, microbial biomass, $\mathrm{N}$ forms, density, horizon depth, conductivity, salinity and nutrients. Satkunas et al. (2001) and Ridgway (2002) highlighted the eco- 
logical importance of soil quality as a geoindicator. Ball et al. (1997) analyzed the quality of the soil structure under the impacts of agriculture, which contributes to soil compaction, and evaluated the management of soil. Carter et al. (1997) reviewed examples of functions attributed to the soil that are used to evaluate its quality, and they concluded that soil quality is related to various ecosystem functions performed by soil. MacEwan (1997) discussed the pedological aspects of soil quality that could function as geoindicators, such as roots and voids, aggregate stability and color.

Akker and Schjønning (2004) defined soil compaction as a "density increase of unsaturated soils". Compared with the soil surface, which tends to change under compaction by weather or agricultural preparations, the subsurface horizons tend to increase in density. Thus, subsoil compaction is harmful to soil functions, including its role as habitat for fauna and flora. Johnson (2010) suggested indicators for the conceptualization and applicability of soil quality. Although the author focused on the

\section{Materials and methods}

This work was performed in the Mascates stream valley in the mid-western region of the SCNP, which is located in Jaboticatubas, Minas Gerais State, Brazil (Fig. 1). The field work was developed to recognize the trail, identify the relevant points of degradation and select the location of the trenches.

Twelve trenches were opened, includ-

ing 6 in the trailbed and another 6 in the margins of the main trail. Macroscopic morphological characterizations of the pedological profiles were performed via the collection of disturbed and undisturbed soil samples (Santos et al., 2013). The disturbed samples were air dried and then used to determine the grain size distribution (EMBRAPA, 2011), and certain
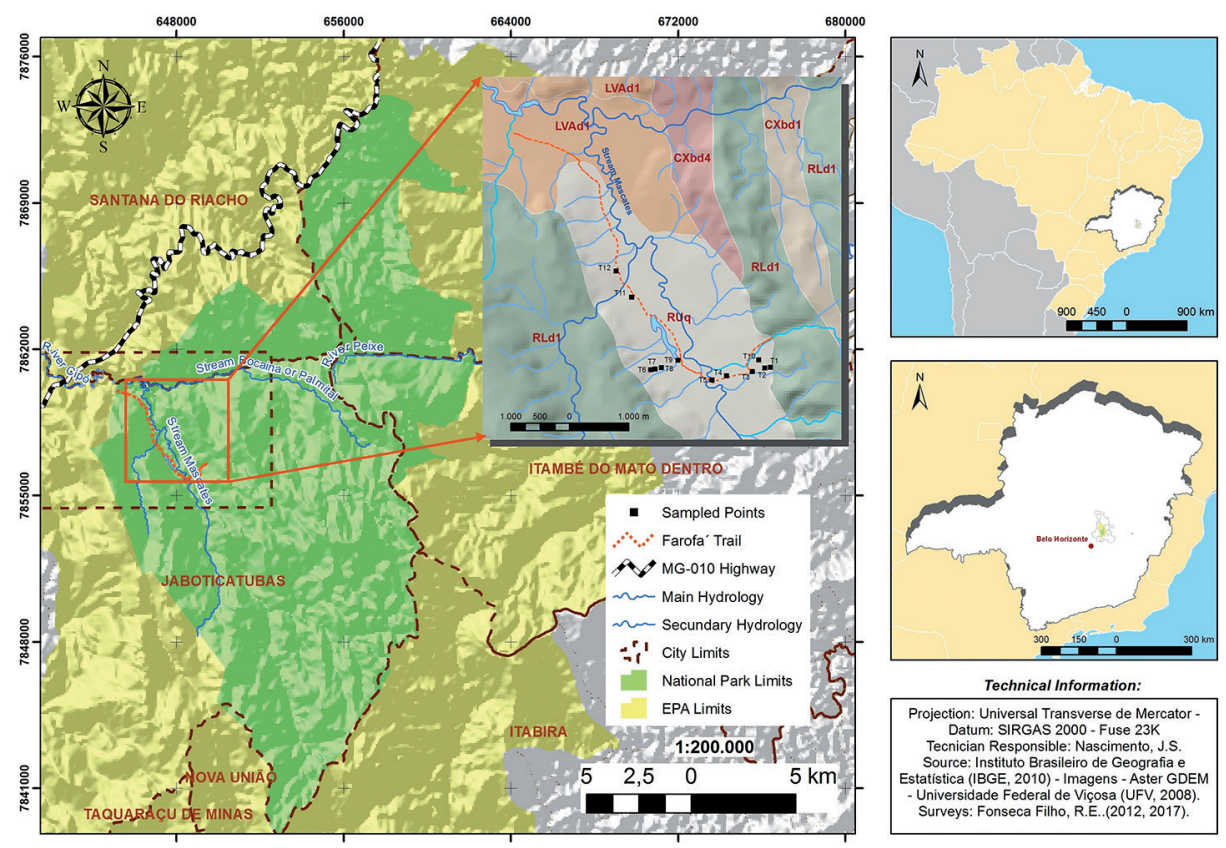

improving the monitoring and management of touristic attractions, such as the Farofa Waterfall trail.

The importance of the trail for geotourism is related to the visitors' understanding of the beauty of the relief, rocks, minerals and sediments as well as the influence of geological and geomorphological processes as pedogenic factors. Hose (1995) stated that geotourism is "the provision of interpretive and service facilities to enable tourists to acquire knowledge and understanding of the geology and geomorphology of a site (including its contribution to the development of the Earth sciences) beyond the level of mere aesthetic appreciation". Compared with the conservationist concept of soils for productivity (erosion), the importance of "pedoconservation" using Sharples (1995) concept of geoconservation ("the conservation of geodiversity for its intrinsic, ecological and (geo)heritage values") is "because the crucial role of soils for human survival, pedodiversity preservation merits special attention, perhaps more than other natural resources (Ibáñez and Bockheim, 2013).

aggregates were separated to determine the porosity using the liquid nitrogen adsorption method N 2 BET (Brunauer et al., 1938; Gregg and Sing, 1982). Undisturbed soil samples were prepared as impregnated thin sections and analyzed via optical microscopy, with a focus on the microporosity, according to criteria of Brewer (1964, 1976) and Bullock et al. (1985a, 1985b).

Figure 1

Study area location and access map; in detail soil thematic chart of Farofa's trail and sampling points. Source: Nascimento (2017) 
A soil penetrometer was applied at 38 points at intervals of $200 \mathrm{~m}$ (Fig. 2) along the trailbed and the left and right margins of the trail from the attraction

\section{Results}

\subsection{Penetrometry}

For all 38 points along the trail, the measurements on the trailbed showed higher values than those along the edges except Point 30, which had margins that were approximately five times more resistant than the trailbed. Although both sides of the trailbed showed similar values of resistance, the resistance of the

Figure 2

Thirty-eight penetrometer measurement points for soil resistance along the trail to Farofa Waterfall (trailbed, left and right margins).

Source: adapted from Fonseca Filho (2012).
(Farofa Waterfall) to the head office (Areias entrance). Three measurements of soil resistance were performed for each point sampled (Leung and Meyer,
2010) using a Geotester ${ }^{\circledR}$ ST-308 penetrometer with a ring dynamometer (SOLOTEST, 2011), which generated average values. trailbed can vary by tenfold compared with that at other points, such as Point 31. The highest resistance values in the trailbed were found in the off-road vehicle traffic zones (from P10 to P38) in association with flooding zones. However, an anomalous value was observed for Point 30, which is located in the off- road vehicle traffic zone on the banks of a grazing area with the presence of horses. A similar finding was observed for Point 20 , which is assigned to the high-value off-road vehicle traffic zone but has soil with a high sand content. These findings indicate the impact of vehicles on the soil compaction of the trail.
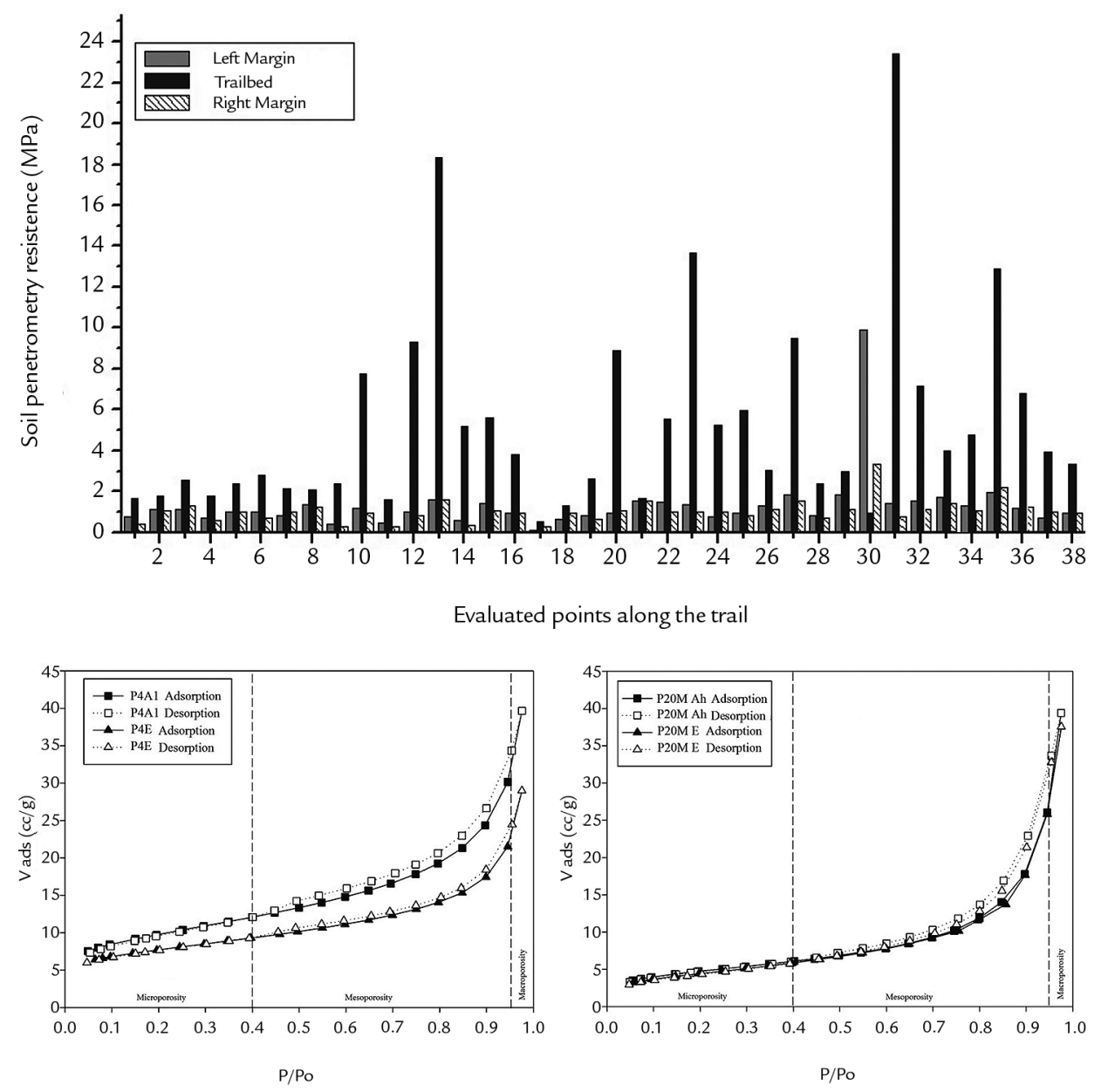

Figure 3

Liquid Nitrogen adsorption-desorption isotherms along the trail margins (P4A1-P4E and P20M Ah-P20M E) and trailbed (P2A-P2AB and P20T A-P20T C).

Source: adapted from Fonseca Filho (2012).
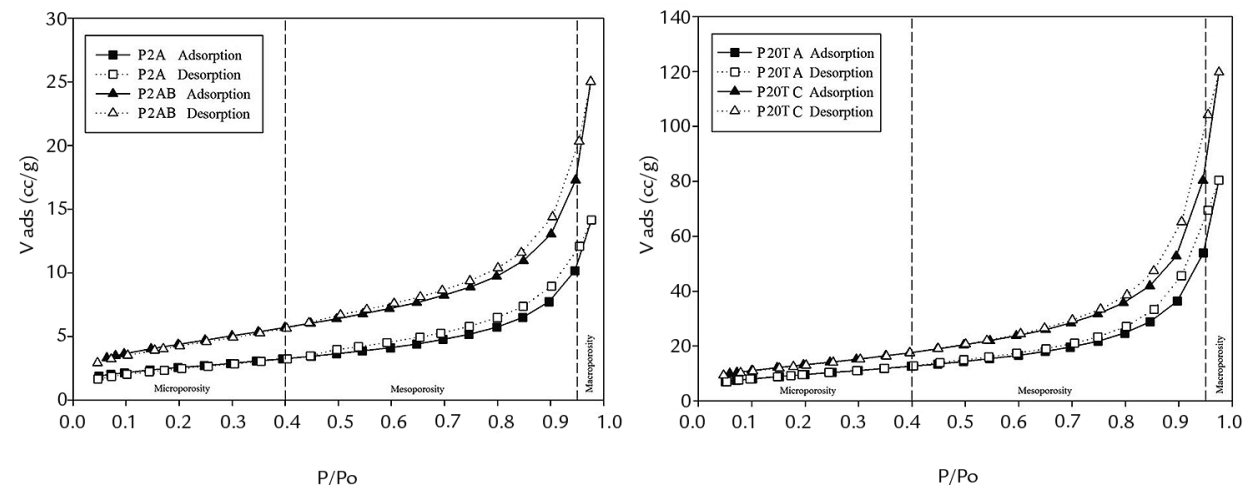


\subsection{Morphological and micromorphological characterization of the soil profiles}

Based on the macromorphological and micromorphological characterization of the 12 profiles, 4 representative profiles were selected, with 2 from the trailbed (P4 and P20M) and the other 2 from the margins (P2 and P20T). Regardless of the location on the trailbed or edge, 2 classes of soil profiles were defined (Table 1, Fig. 4): 1) profiles with an E horizon, such as P4 and P2, which showed the eluviation of organic matter to the deeper horizons, were differentiated from Spodic B horizons (Be) and
Podzol class soils (FAO, 1998) and presented thicknesses between $100 \mathrm{~cm}$ and $200 \mathrm{~cm}$; 2) less developed profiles with an A horizon over the $\mathrm{C}$ horizon and featuring Fluvisol class soils (FAO, 1998). Both types of profiles have a sandy texture, grainy structure, no visible voids and loose consistency.

The micromorphology analysis of the surface horizons shows a groundmass constituted basically of unsorted coarse material with a grain size ranging from very coarse sand to silt (Fig. 4).
The frequency distribution of the fine material ranges from very few to few in the $\mathrm{A}$ and $\mathrm{E}$ horizons, respectively. The basic orientation pattern is random, and the related distribution is enaulic to chitonic. The grade of pedality is moderately to strongly developed in the $\mathrm{A}$ and $\mathrm{E}$ horizons, respectively. In P4, we found a floating zone; and in P11, we found a sandy zone; these characteristics contribute to clay and sandy texture formation, respectively, thus confirming the granulometry (Table 1).

\begin{tabular}{|c|c|c|c|c|c|c|c|c|}
\hline Location & Profile & Horizon & $\begin{array}{l}\text { Depth } \\
(\mathrm{cm})\end{array}$ & Color (Munsell) & Sand & Silt & Clay & Textural Class \\
\hline & & & & \multicolumn{5}{|c|}{$\mathrm{dag} / \mathrm{kg}$} \\
\hline \multirow{8}{*}{$\begin{array}{l}\cdot \frac{n}{\bar{E}} \\
\frac{\bar{\omega}}{\tilde{\pi}} \\
\sum\end{array}$} & \multirow{5}{*}{ P4 } & $\mathrm{A} 1$ & $0-10$ & 7.5YR $8 / 0$ & 20 & 66 & 14 & Sandy Silt Loam \\
\hline & & A2 & $10-19$ & 10YR $5 / 3$ & 59 & 34 & 7 & Sandy Loam \\
\hline & & A3 & $19-54$ & 10YR 6/4 & 63 & 30 & 7 & Sandy Loam \\
\hline & & $E$ & $54-80$ & 10YR 8/8 & 8 & 84 & 8 & Silt Loam \\
\hline & & $\mathrm{Be}$ & $80-145+$ & 10YR 4/4 & 52 & 46 & 2 & Sandy Loam \\
\hline & \multirow{3}{*}{ P20M } & Ah & $0-45$ & 7.5YR $6 / 2$ & 80 & 11 & 9 & Loamy Sand \\
\hline & & $E$ & $45-91$ & 10YR 5/2 & 72 & 15 & 13 & Sandy Loam \\
\hline & & $\mathrm{Be}$ & 91-129+ & $10 Y R 4 / 3$ & 72 & 16 & 12 & Sandy Loam \\
\hline \multirow{5}{*}{ 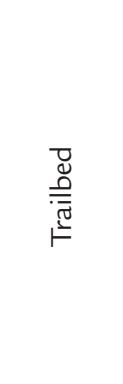 } & \multirow{3}{*}{ P2 } & A & $0-40$ & 10YR 6/4 & 64 & 30 & 6 & Sandy Loam \\
\hline & & $A B$ & $40-55$ & $2.5 Y 7 / 6$ & 60 & 35 & 5 & Sandy Loam \\
\hline & & B1 & $55-84+$ & $2.5 Y 7 / 8$ & 59 & 37 & 4 & Sandy Loam \\
\hline & \multirow{2}{*}{ Р20T } & A & $0-28$ & $2.5 Y 3 / 2$ & 74 & 15 & 11 & Sandy Loam \\
\hline & & C & $28-70$ & $2.5 Y 4 / 2$ & 65 & 19 & 16 & Sandy Loam \\
\hline
\end{tabular}

* P2E and P2Be samples were not analyzed.

Voids occur inside and across aggregates. According to the morphological classification of Brewer (1964), complex packing voids (Bullock, 1985a) occur between grains and small aggregates in the upper horizon and channels in the $\mathrm{E}$ horizon. Complex packing voids are meso- sized $(30-75 \mu \mathrm{m})$ to micro-sized $(5-30 \mu \mathrm{m})$ (Brewer, 1976), and the channel is larger. The total void space as a proportion of the groundmass changes from $10 \%$ in the $\mathrm{A}$ horizon to $20 \%$ in the $\mathrm{E}$ horizon. The voids do not exhibit orientation patterns, and voids with compaction features (flat,
Table 1

Profile characterization of the margins and trailbed.

horizontally elongated with flat ends) are not commonly observed in compacted soils (Brewer, 1964, 1976; Chauvel, 1979; Bullock et al., 1985a; Stoops and Jongerius, 2003; Castro, 2008). Pedofeatures, such as coating, infrequently occur in certain upper horizons in the trailbed.

\subsection{Textural porosity (nitrogen liquid adsorption)}

The adsorption-desorption of liquid nitrogen by the BET method in the aggregates showed that the voids with a smaller size (cavities or interstices) in the trailbed require more pressure and a

greater amount of $\mathrm{N}_{2}$ to be filled (Fig. 3). Bruand and Cousin (1995) observed that during the compaction process, porosity decreases with the presence of clay soils. Although soil was not monitored over a considerable period of time, none of the samples were typically classified as having a clay texture. Thus, all samples were predominantly sandy with smaller quantities of silt and clay (Table 1). 


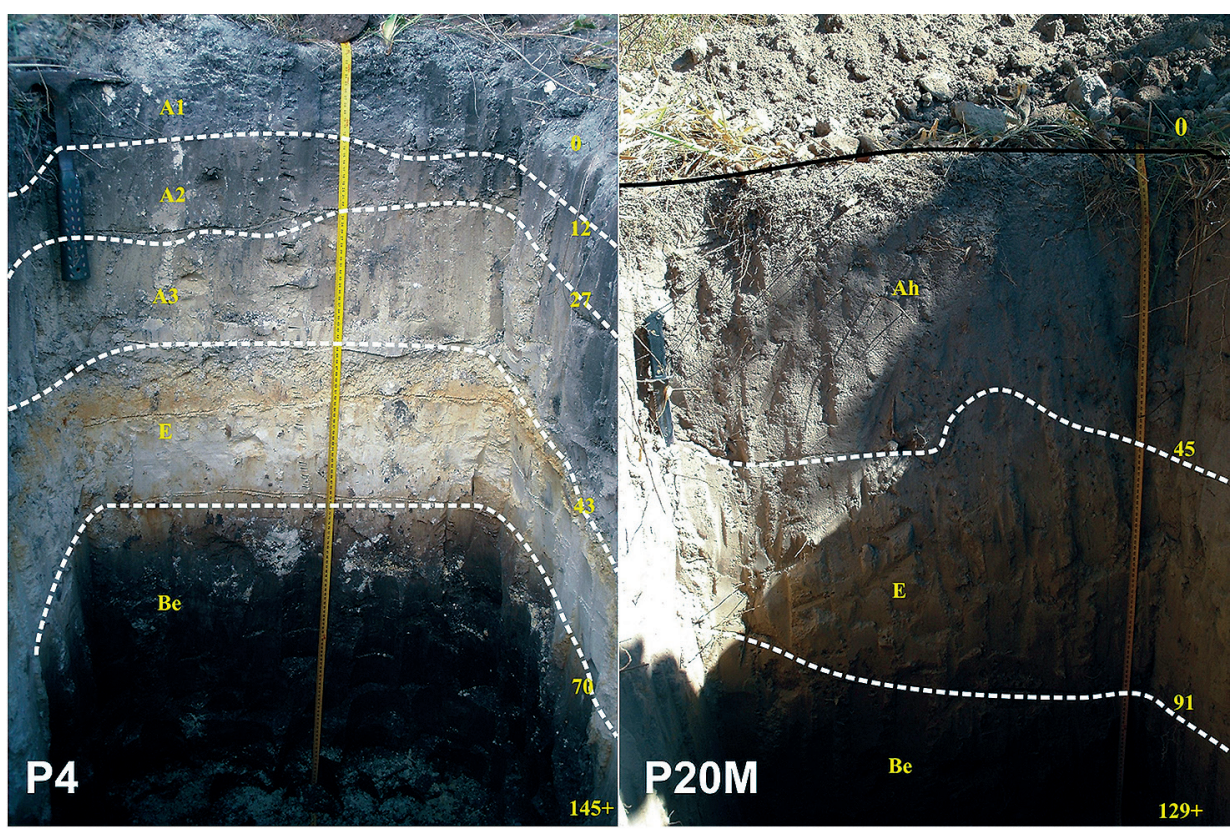

Figure 4

Pedological profiles of horizons P4 and P20M (margins of trail) and P2 and P20T (trailbed).

Source: adapted from Fonseca Filho (2012).

The isotherms of type 3 are generally convex throughout the adsorption process, indicative of a weak interaction between gas and solids related to physical forces (Gregg and Sing, 1982). These forces indicate the prevalence of physical interactions over chemical ones between aggregates. This finding strengthens the perception that the soils in the study area have a high sand fraction that likely consists almost entirely of quartz grains because of the dominant lithology, which is rich in quartz (quartzites, diamictites and fluvial sediments). In the present work, the strong presence of the quartz sand fraction justifies the prevalence of physical interactions. In addition, the high stability

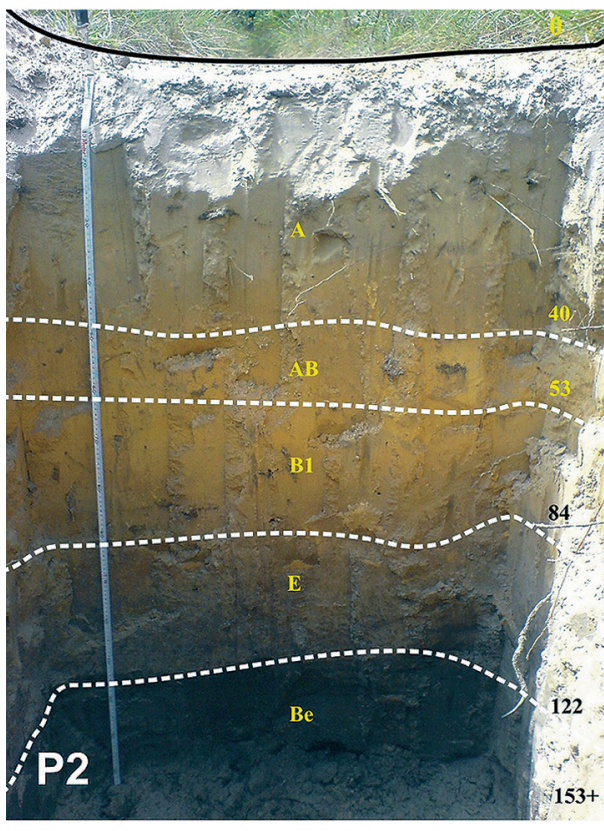

of quartz grains to chemical weathering leads to the formation of cavities instead of voids on the surface of the grains. According to Condon (2006), isotherm type 3 "is characteristic of a material, which is not porous, or possibly macroporous, and has a low energy of adsorption".

The initial hypothesis of the work (greater compaction in the trailbed) is also confirmed in the void distribution and cumulative areas in the surface horizons (typically A horizon) of the trailbed, such as P2A and P20T A. Józefaciuk et al. (2004) observed that soil organic matter affects the structure and properties of the voids and promotes decreased microaggregation

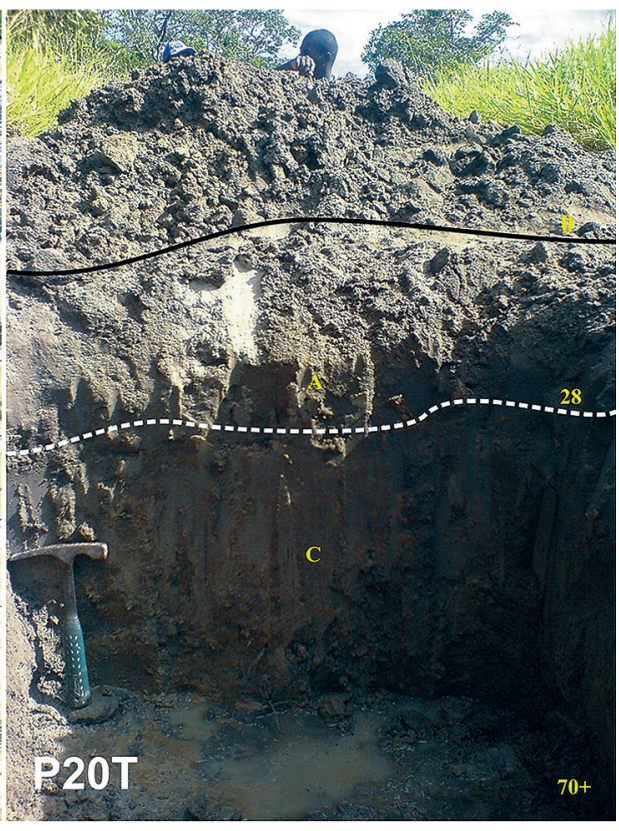

and micropore volume, respectively. Therefore, acid and alkaline treatments are recommended, and continuing studies are required to identify the soil porosity of the trail. The decrease in void size in the $\mathrm{B}$ horizon observed by Chretien and Peter (1987) in soils of alluvial terraces of the Saône River, France, was also observed in certain horizon samples at our study site, such as P4E and P2B1 (Table 1), which indicated the illuviation of clay to the lower horizons (Fig. 4). Although the $B$ horizon samples were not analyzed via the $\mathrm{N}_{2} \mathrm{BET}$ method, the horizons immediately above these horizons (A) demonstrate that the trailbed samples exhibited a decreased pore size (Fig. 5). 


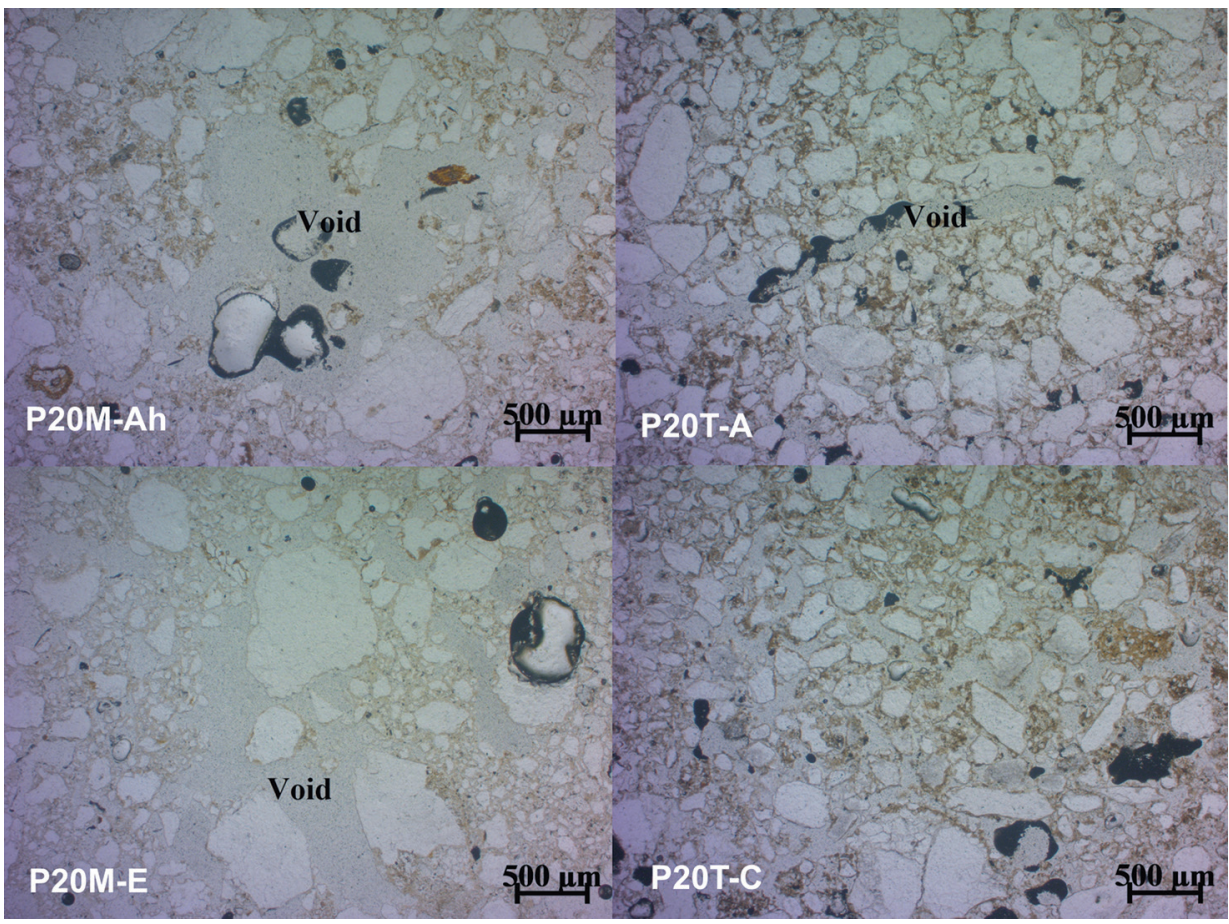

Figure 5

Photomicrography of horizons Ah and E (P20M profile) and Horizons A and C (P20T profile), which correspond to the surface and subsurface horizon profiles. Source: adapted from Fonseca Filho (2012).

\section{Discussion}

Public use of natural areas, such as conservation areas, leads to negative environmental impacts, such as soil compaction and other effects (including erosion and vegetation loss). Few studies have related these impacts to public use and considered pedological aspects, such as the macromorphology and micromorphology. A review of a wide range of studies on soil micromorphology, porosity, compaction and the relationships among these characteristics demonstrates that most studies have focused on agriculture and geotechnical engineering and present an economistic perspective of environmental conservation. Studies of soil porosity in agriculture are related to compression by the cultures themselves and the machinery used for preparation, planting and harvesting. Other studies focused on the "ecology of recreation" (Liddle, 1997; Hammitt and Cole, 1998), limits of acceptable change (Stankey et al., 1985), tourism carrying capacity (Cifuentes Arias, 1992) and other management methodologies related to visitation have not considered these pedological indicators.

Isotherms of type 3 (Gregg and Sing, 1982) were observed, which indicates that the samples have porosity that may not be compatible with the detection range of the $\mathrm{N}_{2}$ BET method. Research has shown that this technique is hardly applicable to soils with high quartz sand fractions. Quartz is a mineral that is highly resistant to chemical weathering, and high levels of quartz performance result in more cavities than pores. The surface area of these cavities is larger than the depth, whereas the surface area of pores is smaller than the depth. Therefore, the chemical dissolution of quartz grains does not produce wells with a depth greater than the perimeter.

Porosity analyses are frequently based on the hypothesis that soil presents two distinct temporal compartments of different origins (Cousin et al., 1994): structural porosity, which is related to the action of external agents (climatic factors, living organisms and agricultural use), and textural porosity, which results from the set of elementary particles (clay, silt and sand) and the voids between them. Therefore, textural porosity can vary widely depending on the nature of the elementary particles (particle size and mineralogy) and water status (Cousin et al., 1994). Textural porosity can be divided into two sub-compartments (Fiès, 1984; Cousin et al., 1994): lacunar porosity, which is caused by voids resulting from interactions between clay particles and the grains of the skeleton phase; and clay porosity, which is caused by the innate voids in the structure of these particles. When a soil undergoes compaction, the structural compartment is preferentially affected. Except for sandy soils and silty soils, the textural compartment is generally not modified under conditions with pressures of less than several dozens of
MPa (Cousin et al., 1994).

Micromorphology analyses identified several features of soil compaction that occur through the formation of horizontal voids, such as in P20T A, and decreased of texture in bottom horizons, as P20M E and P20T C (Fig. $3)$. The textural porosity is correlated with an increase in the pressure of $\mathrm{N}_{2}$ in the samples of the subsurface horizons, which indicates a reduction in void size (Fig. 4). This finding has been confirmed by the use other techniques, such as penetrometry and macromorphological pedological analyses, in the studies of Pagliai (1994) and Mermut (2006) on soil management based on the micromorphology and relationship between micromorphology and soil quality, respectively. Simas et al. (2005) and Benites et al. (2007) analyzed soils of high-altitude rocky complexes in Serra do Cipó National Park and noted similar features related to the lithology, such as shallow soils, high aluminum saturation and coarse textures. Although this study did not examine the biological and chemical aspects of the lithology, a relationship with the physical characteristics was observed. This finding indicates the importance of soil compaction as an indicator of soil degradation (Hakansson and Voorhees, 1998), and it can be characterized biologically (Whalley et al., 1994) or physically (Shestak and Busse, 2005). 


\section{Conclusions}

The findings presented in this article show that the trailbed and margins of the main trail to the geotouristic attraction Farofa Waterfall have been distinctly affected by tourist traffic (hiking) and horse traffic (horseback riding) as well as by bicycle and motor vehicle traffic. The results of the pedological analysis, which included penetrometry, macromorphology, micromorphology, and textural porosity measurements, suggest that the void area of the trailbed is smaller than that at the edge. This discrepancy is associated with natural vulnerability as well as human influences through the regular flow of pedestrians, bicycles, horses and motor vehicles.

\section{Acknowledgements}

This paper was derived from the Master's and Doctoral (in development) natural sciences research of the first author at the School of Mines of the Universidade Federal
Land use associated with finite natural resources should be planned in accordance with the sustainability of the processes involved, including macroscopic and microscopic processes, as well as their interrelations. It represents a niche that has not been thoroughly investigated in studies of geotouristic trails and could include the following aspects: training of tour guides for guided trails; development of interpretive panels and leaflets; installation of soil monoliths and different soilscapes along the trail (in trenches) and in visitor centers; and the installation of a soil trail based on the relationships among the textural properties, such as

de Ouro Preto. The authors would like to thank the anonymous reviewer for their suggestions and comments, and they would also like to acknowledge the CNPq, FAPEMIG porosity, and soil compaction according to the micromorphological characteristics. Thus, natural areas, especially protected areas, are increasingly viewed as a counterpoint to the stress inherent in urban life, as suggested by Conway (2010) for the Anglesey Coastal Footpath, UK. The increased number of visitors in these areas has been a global trend. Studies investigating environmental indicators, which should be constantly monitored to reduce soil loss on geotouristic trails because of erosion, strengthen the management of these areas and positively contribute to the experience of visitors during their contact with nature.

\section{References}

AKKER, J.J.H. van den, SCHJØNNING, P. Subsoil compaction and ways to prevent it. In: SCHJØNNING, P., ELMHOLT, S., CHRISTENSEN, B.T. Managing soil quality. Challenges in modern agriculture.Tjele, Denmark: CABI Publishing, 2004. p.163-184.

BALL, B.C., CAMPBELL, D.J., DOUGLAS, J.T., HENSHALL, J.K. O’SULLIVAN, M.F. Soil structural quality, compaction and land management. Eur. J. Soil Sc. n.48, p.593-601, 1997.

BAREN, J.H. van., BOMER, W. Procedures for the collection and preservation of soil profiles. Wageningen: International Soil Museum, 1979. (Technical Paper 1).

BENITES, V.M., SCHAEFER, C.E.G.R., SIMAS, F.N.B., SANTOS, H.G. Soils associated with rock outcrops in the Brazilian mountain ranges Mantiqueira and Espinhaço. Rev. Bras. Bot. v.30, n.4, p.569-577, 2007.

BREWER, R. Fabric and mineral analysis of soils. Huntington: Robert E. Krieger Publications Co., 1964.

BREWER, R. Fabric and mineral analysis of soils. Huntington: Robert E. Krieger Publications Co., 1976.

BRUAND, A., COUSIN, I. Variation of textural porosity of a clay-loam soil during compaction. Eur. J. of Soil Sci, n.46, p.377-385, 1995.

BRUNAUER, S., EMMETT, P.H., TELLER, E. Adsorption of gases in multi molecular layers. J. American Chem. Soc., n.60, p.309-319, 1938.

BUllOCK, P., FEDOROFF, N., JONGERIUS, A., STOOPS, G., TURSINA, T., BABEL, U. Handbook of soil thin section description. Wolverhampton: Waine Research Publications, 1985a.

BULLOCK, P., NEWMAN, A.C.D., THOMASSON, A.J. Porosity aspects of the regeneration of soil structure after compaction. Soil Tillage Research, v.5, n.4, p.325-341, 1985 b.

CARTER, M.R., GREGORICH, E.G., ANDERSON, D.W., DORAN, J.W., JANZEN, H.H., PIERCE, F.J. Concepts of soil quality and their significance. In: GREGORICH, E.G., CARTER, M.R. (Eds.). Soil Quality for crop production and ecosystem bealth. Amsterdam: Elsevier Science Publ., , The Netherlands, 1997. p. 1-19.

CASTRO, S.S. Micromorfologia de solos: base para descrição de lâminas delgadas. Campinas/Goiânia: UNICAMP/UFG, 2008. 
CHAUVEL, A. Iniciação à análise microscópica dos solos. São Carlos, ESALQ/USP, 1979.

CHRETIEN, J., PEDRO, G. Granulométrie, porosité et spectre poral de sols développés sur formations détritiques Cas des terrasses alluviales de la Saône. Cah. ORSTOM. v.23, n.1, p.43-54, 1987.

CIFUENTES ARIAS, M. Determinación de capacidad de carga turistica en areas protegidas. Turrialba: CATIE, 1992.

CONDON, J.B. Surface area and porosity determinations by physisorption: measurements and theory. Amsterdam: Elsevier, 2006.

CONWAY, J.S. A soil trail? - A case study from Anglesey. Wales, UK: Geoheritage, n.2, p.15-24, 2010.

COUSIN, I., LE LAY, C., BRUAND, A. Évolution de la porositè et formation de pores structuraux reliques dans un sol argilo-limoneux soumis à un compactage. C. $R$. Acad. Sci. Paris, n.319, p.797-804, 1994. (Série II).

DELUCA, T.H., PATTERSON IV, W.A., FREIMUND, W.A., COLE, D.N. Influence of llamas, horses and hikers on soil erosion from established recreation trails in Western Montana, USA. Environm. Manag, v.22, n.2, p.255-262, 1998.

EMBRAPA. Manual de métodos de análise de solo. Rio de Janeiro: Empresa Brasileira de Pesquisa Agropecuária, 2011.

FAO. World reference base for soil resource. Rome, Food and Agriculture Organization of the United Nations, 1998.

FIES, J.C. Analyse de la répartition du volume de pores dans les assemblages argile-squelettes: comparaison entre un modèle d'espace poral textural et les données fournies par la porosimétrie au mercure. Agron. n.4, p.319-355, 1984.

FITZPATRICK, E.A. Micromorphology of soils. London: Chapman and Hall, 1984.

FONSECA FILHO, R.E. Qualidade do solo como um geoindicador de alterações ambientais nas zonas de visitação pública do Parque Nacional da Serra do Cipó, MG. Dissertação (Mestrado em Ciências Naturais) - Ouro Preto/MG: Universidade Federal de Ouro Preto, 2012.

FONSECA FILHO, R.E. Patrimônio Pedológico e fatores impactantes ambientais nas trilhas de uso público em Parques do Espinhaço Meridional. Tese (Doutorado em Ciências Naturais) - Ouro Preto/MG: Universidade Federal de Ouro Preto, 2017.

FOX, D.M., BRYAN, R.B., FOX, C.A. Changes in pore characteristics with depth for structural crusts. Geoderma, n.120, p.109-120, 2004.

GREGG, S.J., SING, K.S.W. Adsorption surface area and porosity. London: Academic Press, 1982.

HAKANSSON, I., VOORHEES, W.B. Soil compaction. In: LAL, R., BLUM, W.H., VALENTIN, C., STEWART, B.A. (Eds.). Methods for assessment soil degradation. Boca Raton: CRC Press, 1998. p. 167-179.

HAMMITT, W.E., COLE, D.N. Wildland recreation: ecology and management. New York: John Wiley \& Sons, 1998.

HOSE, T.A. Selling the story of britain's stone. Environmental Interpretation, v.10, n.2, p.16-17, 1995.

IBÁÑEZ, J.J., BOCKHEIM, J. (Ed.) Pedodiversity. Boca Raton: CRC Press, 2013.

ICMBIO. Plano de Manejo da Área de Proteção Ambiental Morro da Pedreira e do Parque Nacional da Serra do Cipó. Brasília: Instituto Chico Mendes de Conservação da Biodiversidade, 2009.

ICMBIO. Turismo nos Parques. Brasília: Instituto Chico Mendes de Conservação da Biodiversidade, 2010.

JOHNSON, D.W. Soil quality: some basic considerations and case studies. USDA Forest Service Proceedings, RMRS, 2010.

JORDAN, M. Ecological impacts of recreational use of trails: a literature review. The Nat. Conserv. n.1, p.1-6, 2000.

JÓZEFACIUK, G., SOKOLOWSKA, Z., HAJNOS, M. Physical chemistry of soil. Lublin, EU: Surface and properties.

KUBIËNA, W.L. Micropedology. 1938. Ames, Collegiate Press, 2004.

KUTIEL, P., ZHEVELEV, H., HARRISON, R. The effect of recreational impacts on soil and vegetation of stabilized Coastal Dunes in the Sharon Park, Israel. Ocean \& Costal Manag, n.42, p.1041-1060, 1999.

LEUNG, Y.-F., MEYER, K. Soil compaction as indicated by penetration resistance a comparison of two types of penetrometers. Tec. Research Manag, n.1, p.370-375, 2010. 
LIDDLE, M. Recreation ecology: the ecological impact of outdoor Recreation and ecotourism. London: Chapman \& Hall, 1997.

MACEWAN, R.J. Soil quality indicators: pedological aspects. In: GREGORICH, E.G., CARTER, M.R. (Eds.), Soil quality for crop production and ecosystem health. Amsterdam, the Netherlands: Elsevier Science Publ., 1997. p. 143-166.

MERMUT, A.R. Micromorhology and soil quality. In: Encyclopedia of Soil Science. Boca Raton, USA: R. Lal, 2006. p. 1077-1080.

MUNSELL. Munsell Soil-Color Charts. Grand Rapids, USA, Munsell Color, 2010.

MURPHY, C.P., BULLOCK, P., BISWELL, K.J. The measurement and characterisation of voids in soil thin sections by image analysis - part II: aplications. Eur.J. Soil Sci, v.28, n.3, p.509-518, 1977.

PAGLIAI, M. Micromorhology and soils management. Develop. Soil Sci, n.22, p.623-640, 1994.

PRISKIN, J. Physical impacts of four-wheel drive related tourism and recreation in a semi-arid, natural coastal environment. Ocean Coastal Manag, n.46, p.127-155, 2003.

RIDGWAY, J. Soil and sediment quality. http://www.lgt.lt/geoin/files/. (accessed 05.01.2010), 2002.

SANTOS, R.D., LEMOS, R.C., SANTOS, H.G., KER, J.C., ANJOS, L.H.C., SHIMIZU, S.H. Manual de descrição e coleta de solo no campo. Viçosa: Sociedade Brasileira de Ciência do Solo, 2013.

SATKUNAS, J., NYAMBE, I., SIMPSON, C. Geoindicators - a technique that can strenghthen environmental monitoring in Sourthern and Eastern Africa. Lusaka: International Geoindicators Course, p.1-7, 2001.

SCHAEFER, C.E.G.R., ALBUQUERQUE FILHO, M.R., FERNANDES FILHO, E.I., ALBUQUERQUE, M.A., GALVÃO, J.C.C. Microstructural effects of compost and fertilizer incorporation in a clayey ultisol cultivated with maize, from Coimbra, MG. R. Ci. Funec. n.2, p.59-64, 1999.

SCHAEFER, C.E.R., MICHEL, R.F.M., CHAGAS, C., FERNANDES FILHO, E., VALENTE, E., SOUZA, E., VASCONCELOS, B., SABOYA, A. Relatório do levantamento pedológico, geomorfológico e geológico: diagnóstico do meio físico da APA do Morro da Pedreira e Serra do Cipó - subsídios ao plano de manejo. Viçosa: Universidade Federal de Viçosa, 2008.

SHARPLES, C. Geoconservation in forest management - principles and procedures. Tasforests, v. 7, p. 37 - 50 (Forestry Tasmania, Hobart, Dec. 1995).

SHESTAK, C.J., BUSSE, M. D. Compaction alters physical but not biological indices of soil health. Soil Sci. Soc. Am. J, n.69, p.236-246, 2005.

SILVA, G.L., FREITAS, M.A., SILVEIRA, V.D. Geologia da região centro-oeste do Parque Nacional da Serra do Cipó: municípios de Jaboticatubas e de Santana do Riacho, MG. Belo Horizonte: Universidade Federal de Minas Gerais, Instituto de Geociências, 2007. (Trabalho de Graduação).

SIMAS, F.N.B., SCHAEFER, C.E.G.R., FERNANDES FILHO, E.I., CHAGAS, A.C., BRANDÃO, P.C. Chemistry, mineralogy and micropedology of highland soils on crystalline rocks of Serra da Mantiqueira, southeastern Brazil. Geoderma. n.125, p.187-201, 2005.

SOLOTEST. Manual do penetrômetros para solos, com anel dinamométrico. Bela Vista, SP: Solotest, 2011.

SOUZA, Z.M., MARQUES JÚNIOR, J., COOPER, M., PEREIRA, G.T. Micromorfologia do solo e sua relação com atributos físicos e hídricos. Pesq. Agropec. Bras, n.3, p.487-492, 2006.

STOOPS, G. Guidelines for analysis and description of soil and regolith thin sections. Madison, USA: Soil Science Society of America, 2003.

STOOPS, G., JONGERIUS, A. Proposal for a micromorphological classification of soil materials. I. A classification of related distribution of coarse and fine particles. A reply. Geoderma. n.19, p.247-249, 2003.

WHALLEY, W.R., DUMITRY, E., DEXTER, A.R. Biological effects of soil compaction. Soil \& Til. Res, n.35, p.53-68, 1994.

Received: 29 August 2016 - Accepted: 7 August 2017. 